\title{
A Factor Analysis and Reliability on Leadership Self-efficacy, Effective Leadership Behaviour and Managerial Job Performance
}

\author{
Shehu Inuwa Galoji", Fais Ahmad, Husna Johari \\ Department of Business University Utara Malaysia \\ mogaloji@yahoo.com, fais@uum.edu.my,husna@uum.edu.my
}

\begin{abstract}
The recent financial crisis that hits the global market and cripple a lot businesses around the world is not without its causes. One of this causes is the role of the leadership or management in organisations. Recent business scandals that hit countries like American companies that were hit hard and other nations had been attributed to leaders or management greed, malpractices and unethical attitudes from the side of the leadership. This objectives of this study is aimed at examining the relshionship between the leadership self efficacy, effective leadership behaviour and managerial job performance.. Part of what is considered in this study is wether self discipline, perceived credibility, serve, challenge and involve LSE are related to task and contextual managerial performance with a mediating effect of effective leadership behaviour.
\end{abstract}

Keywords Leadership Self Efficacy, Managerial Job Performance, Effective Leadership Behaviour, Banks, Nigeria

\section{Introduction}

Organisational performance in general or its success/ failure in particular had been generally or in part been attributed to the managerial job performance of the leaders in the organisation. It is argued that the effective performance of today's organizations depends on its ability to survive in other as to perform its stated objectives and mission so as to maintain its favorable earnings towards the sustenance of the value of its asset (Yukl, 2008). Nigeria's banking sector witness a robust growth in 2007 even though the consolidation by the carried out by the Nigeria's central bank which reduce the number of banks to 25. In 2007, the central govenor of Nigeria then reported that as a result of the banks consolidation which was carried out, the banking sector is now efficient, strong and healthy. He affirmed that over 1 billion dollars of foreign direcrt investment had gone into the sector within 12 months, non perfoming loans have decrease, total deposits incresed. The banking sector becomes one of first ten in Africa among the fast growing banks worldwide. The banks makes expansion around the globe and improve in technology hence most of them receive national and international awards of excellence (Cowry research, 2009).

Subsequently, the Nigerian economy went into a situation

* Corresponding author:

mogaloji@yahoo.com(Shehu Inuwa Galoji)

Published online at http://journal.sapub.org/economics

Copyright (C) 2012 Scientific \& Academic Publishing. All Rights Reserved that lead it to falter to which it experience a crisis situation which is triggered by the global events as the Nigeria stock market collapse by $70 \%$ in 2009 . Thus most of the banks had to be rescued as they are recording deteriorating performance (Sanusi, 2010). This a direct result of leadership meltdown in the banking sector (Awoyemi, 2009; Proshare, 2009). Thus the central bank governor of Nigeria $(\mathrm{CBN})$ directed the removal of 5 bank leaders that resulted to the deteriorating performance of their banks as only 4 banks in Nigeria were ascertained to be strong. Sanusi (2010) observed that as the Nigerian banks thus rapidly grew in size and complexity but unfortunately their board and managers do not perform their functions as they were carried away by the sence of wellbeing on the year after yaer growth in assats and profits. Furthermore, the banks boards and executives were not equiped to run their institutions hence not acquainted with their managerial job roles. Yukl (2008) argued that one of the major problem to leaders influence on performance is the oversight by the leaders towards their organisations performance determinants.

As a result of the central role position they occupy within their group, leaders are often associated with the performance of their team or organization based on the contribution they offer in their managerial role (Lord \& Maher, 1991; Phillips \& Lord, 1981; Giessner, Knippenberg $\&$ Sleebos, 2009). Thus the impact people have in leadership position in the society is undoubtedly great as their actions may determine to a large extent the performance of their organizations (Giesner et al, 2009). McCloy, Campbell, and Cudeck (1994) defined performance as those behaviours or 
the actions that are in sum relevant to the goals and objectives of the organisation. Furthermore, they argued that performance is not the outcome, consequence, result of the behavior or the action, rather performance is the action itself.

However, the managerial job performance of the leaders in the Nigerian banking industry needs to be ascertained i.e.their task and contexual performance as the success of this sector is attached to the ability and perfomance of the management. As such this study recommends the identification of the management of their ability to perform their task and contexual roles as submitted by Borman and Motowidlo (1993).

Most of the personnel research in the past had considered job performance factor in a single job performance factor (eg Campbell, McCloy, Oppler \& Sager, 1993) hence relying on a singular factor model have impeded progress in understanding predictor criterion relations (Campbell et al. 1993; Conway, 1996). Rodney A. McCloy, John P. Campbell, and Robert Cudeck (1994) assumed that virtually all performance in any job is multidimentional and at the same time the substantive content of performance can be discused in terms of basic dimensions such as identified in job description and task analysis. Semader et al (2006) conducted their study by using a single item measure to assess managerial performance therefore it does not address the multidimensionality of job performance. They also sugested that they did not measure the dual dimensions of performance measure hence accounting for the multidimens ional aspects of managerial job performance is certainly an important avenue for future research direction. It was also observed by Paglis (2010) that the weaker result from the work of Semader et al (2006) could be best explained from the inconsistency between the scope of the LSE and performance measures as they used a single-item overall performance appraisal score to measure managerial performance (Paglis, 2010).

Based on the managerial issues and the research/theoritic al gaps ascertained from the background, this study intends to study the managerial job performance of Borman and Motowidlo (1993) task and contexual performance as suggested by Semader et al (2006). Secondly, still based on the managerial issues in relation to the leaders deceptive behaviours, this study will consider self discipline, serve, involve, project credibility and challenge LSE as suggested by Anderson et al (2008). This study is aimed at determining the influence of LSE on managerial job performance, thus this study intends to achive a specific objective of determining the influence of leadership self-efficacy on managerial job performance

\section{Methodology}

The theoretical underpinning of this study is self-efficacy theory. In the context of self-efficacy theory, perceived self efficacy operates as as central factor that acts in the self-regulatory mechanisms which governs human motivation and actions (Bandura \& Wood, 1989) hence the stronger a person's perceived self-efficacy to achieve a certain level of performance, the higher the persons set goals for themselves and thus they become firm to such commitment on such goals (Bandura \& Wood, 1989).

This paper is the outcome of a data collection of an ongoing research, thus it reports the factor analysis and the reliability of the instruments under study. This study uses the questionnaire form of data collection. Questionnaires are designed to measure attitudes which also allows respondents to give their indication on how they strongly agree or dis-agree with a statement that are made based on the ranges of positive to negative rating on an attitudinal object (Zikmund, 2010). In this case, 1000 questionnaires were administered face to face by the researcher. Before then, the questionnaire was sent to experts for face validity and suggestions. This questionnaire consist of questions that covers the the variables considered in this study which are managerial job performance (task and contexual performance)' Leadership self efficacy with five dimensions (self discipline, serve, project credibility, challenge and involve LSE) and the mediating effect which is effective leadership behaviour. This questionnaire gives the respondents options based on the 5 point Likert style. This options ranges from (1) unable; (2); "low" (3); "moderate" (4); "high" (5); "certain". Thereafter, the reliability test was conducted.

\section{Results}

This study uses SPSS version 16 for the purpose of conducting the analysis. In the first place, the data collected were screened and imputed into the SPSS software. Out the 457 questionnaires considered for the analysis, 44 cases turned to be outliers, hence they were deleted and not considered for the in the analysis. The next step was the factor analysis and reliability test based on variables considered in this study. The first is the independent variable which is leadership self efficacy. The independent variable contains five dimensions and in measured by 24 items i.e. self discipline (4), involve (5), serve (5), perceived credibility (5) and challenge (5) LSE. As a result of the factor analysis, 4 items were deleted thus making 20 items to measure LSE. For the number of Items, KMO and Bartlett's Test and Cumulative (see table 2). Reliability test was then conducted on the dimensions and the result shows self discipline (.76), involve (.73), serve (.78), perceived credibility (.81) and challenge (.78) LSE and the overall leadership self efficacy shows a reliability of (.64) (see table1). 
Table 1. Summary result of reliability test of constructs using SPSS version 16 windows

\begin{tabular}{|c|c|c|c|}
\hline Constructs & Dimensions & Number of items & Cronbach Alpha \\
\hline $\begin{array}{l}\text { Leadership Self } \\
\text { efficacy }\end{array}$ & 5 & & \\
\hline Self discipline LSE & & 3 & .76 \\
\hline Involve LSE & & 4 & .73 \\
\hline Serve LSE & & 4 & .78 \\
\hline Challenge LSE & & 4 & .81 \\
\hline Perceived credibility LSE & & 5 & .78 \\
\hline Total items & & 20 & .64 \\
\hline $\begin{array}{c}2 \quad \text { Effective Leadership } \\
\text { Behavior }\end{array}$ & 3 & & \\
\hline $\begin{array}{l}\text { Directional leadership } \\
\text { behavior }\end{array}$ & & 5 & .85 \\
\hline Relational leadership behavior & & 5 & .85 \\
\hline $\begin{array}{l}\text { Effective communication } \\
\text { behavior }\end{array}$ & & 3 & .72 \\
\hline Total items & & 13 & .71 \\
\hline $\begin{array}{l}\text { Managerial Job } \\
\text { Performance }\end{array}$ & 2 & & \\
\hline Contextual job performance & & 5 & .83 \\
\hline Task job performance & & 5 & .88 \\
\hline Total items & & 10 & .79 \\
\hline
\end{tabular}

The second factor analysis and reliability test was conducted on the mediator variable which is effective leadership behavior. The mediator variable was measured by 17 measures i.e. directional leadership (5), relational leadership (7) and strategic leadership (5). The result of the factor analysis shows that 4 items were also to be deleted thus directional leadership was to be measured by the 5 measures, relational leadership 7. After deletion, strategic leadership had to be renamed to effective communication and to be measure by 3 items. For the number of Items, KMO and Bartlett's Test and Cumulative (see table 2). The reliability test was conducted on the dimensions which the result shows that directional leadership (.85), relational leadership (.85) and effective communication (.72). The overall cronbach alpha score of effective leadership behavior arrived at .71 (see table 1).

Table 2. Summary of factor analysis on the constructs using SPSS version 16 windows

\begin{tabular}{cccc}
\hline Constructs & Items & $\begin{array}{c}\text { KMO and } \\
\text { Bartlett's } \\
\text { Test }\end{array}$ & Cumulative \\
\hline $\begin{array}{c}\text { 1. Leadership } \\
\text { Self efficacy }\end{array}$ & 20 & .748 & 60.321 \\
$\begin{array}{c}\text { 2. Effective } \\
\text { Leadership } \\
\text { Behaviour }\end{array}$ & 13 & .810 & 62.696 \\
$\begin{array}{c}\text { 3. Managerial } \\
\text { Job }\end{array}$ & 10 & .806 & 63.434 \\
Performance & & & \\
\hline
\end{tabular}

Factor analysis and reliability test was then conducted on the dependent variable which is managerial job performance. The dependent variable was measured with 13 items which are contextual performance (7) and task performance (6).
The factor analysis on this items resulted in the deletion of 3 items. The rotated matrix shows both contextual and task performances are to be measured by 5 items each. For the number of Items, KMO and Bartlett's Test and Cumulative (see table 2). Subsequently, reliability test was conducted and the result shows that contextual performance (.83) and task performance (.88). The overall cronbach alpha value of managerial job performance is .79 (see table 1).

\section{Discussion}

The result of the factor analysis and reliability test shows that the items administered to the respondents in the Nigerian banking sector is suitable for the environment under study thus it can be used to continue the further analysis of the study i.e. the correlations among the variables under the study, the regression analysis and the hierarchical regression in the test for mediation. The normality of the data in the first place shows the deletion of 44 outliers which gives us the impetus to go for the factor analysis. The result of the factor analysis shows the correlation matrix of all the variables to contain above .30; the KMO Bartlett's test is above .50, the anti image matrices devoid of .40, the communalities above .50 , the cumulative also up to .60 and the rotated matrix did not cross load. The subsequent reliability test shows all above .60 which according to Nunally and Bernstein (1994), a Cronbach alpha value of .70 is considered good and above 0.60 is also acceptable thus this value is found suitable (see appendix $F$ ).

\section{Conclusions}


As this paper is work in progress, the aim of this paper is to present the factor analysis and the reliability test of the study conducted in other as to present the concept of the work and present the progress so far made in this study. The result of the factor analysis and reliability test thus gives the avenue to continue with this study.

\section{REFERENCES}

[1] A. Bandura, and Wood, R. (1989) Effect of perceived controllability and performance standards on self-regulation of complex decision making. Journal of Personality and Social Psychology, 56, 805-814.

[2] A. Jenkins. (1994). The role of managerial self-efficacy in corporate compliance with the law. Law and Human Behavior, $18,71-88$.

[3] A. K. Barling, and E. Kelloway. (2001) Transformational leadership or the iron cage: Which predicts trust, commitment, and team efficacy. The Leadership and Organization Development Journal, 22, 315-320.

[4] A. Thomas. (1988). Does leadership make a difference. Administrative Science Quarterly, 33, 388-400

[5] C. Hoyt. (2005). The role of leadership efficacy and stereotype activation in women's identification with leadership. Journal of Leadership \& Organizational Studies, $11,2-14$.

[6] C. Hoyt, and J. Blascovich. (2003). Transformational and transactional leadership in virtual and physical environments. Small Group Research, 34, 678-715.

[7] C. Hoyt, S. Murphy, S. Halverson and C. Watson. (2003). Group leadership: Efficacy and effectiveness. Group Dynamics: Theory, Research, and Practice, 7, 259-274.

[8] D. Jung and J. Sosik. (2003). Group potency and collective efficacy. Group Organization Management, 28, 366-391.

[9] D. Miller and J. Shamsie. (2001). "Learning across the life cycle: experimentation and performance among Hollywood studio heads". Strategic Management Journal, Vol. 22 No. 8, pp. $725-45$.

[10] D. W. Anderson, H. T. Krajewski, R. D. Goffin, and D. N. Jackson. (2008) A leadership self-efficacy taxonomy and its relation to effective leadership. The Leadership Quarterly 19 595-608.

[11] F. Luthans and S. J. Peterson. (2002). Employee engagement and manager self-efficacy: Implications for managerial effectiveness and development. Journal of Management Development, 21(5), 376-387.

[12] F. L. Schmidt, J. E. Hunter and A. N. Outerbridge (1986) Impact of job experience and ability on job knowledge, work sample performance, and supervisory ratings of job performance. Journal of Applied Psychology, 71, 432-439.

[13] G. Chen and P. Bliese. (2001). The role of different levels of leadership in predicting self- and collective efficacy: Evidence for discontinuity. Journal of Applied Psychology, 87, 549-556.
[14] Govadd. (2009). An assessment of current development in the nigerian economy and the central bank of nigeria (CBN) policy action 7-7 09

[15] G. Yukl and D. D. Van Fleet. (1992). Theory and research on leadership in organizations. In M. D. Dunnette \& L.M. Hough (Eds.), 2nd Ed. Handbook of Industrial and Organizational Psychology, Vol. 3 (pp. 147-197). Palo Alto, CA: Consulting Psychologists Press.

[16] J. F. Hair, Jr., W.C. Black, B. J. Babin, R. E. Anderson, Multivariate Data Analysis Pearson Prentice Hall

[17] K. Ng, S. Ang, and K. Chan. (2008). "Personality and leader effectiveness: a moderated mediation model of leadership self-efficacy, job demands, and job autonomy". Journal of Applied Psychology, Vol. 93, pp. 733-43.

[18] K. Y. Chan, and F. Drasgow, (2001). Toward a theory of individual differences and leadership: Understanding the motivation to lead. Journal of Applied Psychology, 86 (3), 481-498.

[19] L.S. Sanusi. (2010). "The Nigerian Banking Industry: what went wrong and the way forward" Being the full text of a Convocation Lecture delivered at the Convocation Square, Bayero University, Kano, on Friday 26 February, 2010 to mark the Annual Convocation Ceremony of the University Central Bank of Nigeria Governor's Speech.

[20] M. J. Ree, J. A. Earles, and M. S. Teachout (1994) Predicting Job Performance: Not Much More Than g Journal of Applied Psychology . Vol. 79, No. 4, 518-524

[21] M. S. Christian, A. S. Garza and J. E. Slaughter (2011) Work Engagement: A Quantitative Review and Test of its Relations with Task and Contextual Performance. PERSONNEL PSYCHOLOGY, 64, 89-136

[22] M. M. Chemers, C. B. Watson and S. T. May. (2000). Dispositional affect and leadership effectiveness: A comparison of self-esteem, optimism, and efficacy. Personality and Social Psychology Bulletin, 26, 267-277.

[23] M. Norsiah. (2008) cross-functional new product development (NPD): characteristics, dynamics and NPD performance. PhD thesis submitted to Universiti Sains Malaysia.

[24] O. Awoyemi. (2009) Corporate Governance-Financial Crisis and the Nigerian Leadership Meltdown, MD/CEO of Proshare Nigeria September 28,

[25] Orr, J. M., Sackett, P. R., \& Mercer, M. (1989). The role of prescribed and nonprescribed behaviors in estimating the dollar value of performance. Journal of Applied Psychology, $74,34-40$

[26] Proshare, (2009). The Bull in the China Shop - The New Paradigm in Nigerian Financial Sector In association with mbc newscorp ISSN 1597 - 8842 the state of the market report, Issued on August 22 Vol.1 No. 21.

[27] R. A. McCloy, J. P. Campbell, and R. Cudeck (1994) A Confirmatory Test of a Model of Performance Determinants Journal of Applied Psychology . Vol. 79, No. 4,493-505

[28] R. P. Tett, H. A. Guterman, A. Bleier and P. J. Murphy. (2000). Development and content validation of a "hyperdimensional" taxonomy of managerial competence. Human Performance, 13, 205-251. 
[29] S. J. Motowidlo, J. S. Packard and M. R. Manning (1986) Occupational stress: Its causes and consequences for job performance. Journal of Applied Psychology, 71, 618-629.

[30] S. J. Motowidlo and J, R. Van Scotter (1994) Evidence That Task Performance Should Be Distinguished From Contextual Performance Journal of Applied Psychology. Vol. 79. No. $4.475-480$

[31] S. Kahai, J. Sosik and B.Avolio. (2003). Effects of anonymity, rewards, and leadership style in an electronic meeting system context. The Leadership Quarterly, 14, 499-524.
[32] S. MurphY and E. Ensher. (1999). The effects of leaders and subordinate characteristics in the development of leader-member exchange quality. Journal of Applied Social Psychology, 29, 1371-1394.

[33] S. Taggar and G. H. Seijts. (2003). Leader and staff role-efficacy as antecedents of collective-efficacy and team performance. Human Performance, 16, 131-156.

[34] W. C. Borman and D. H. Brush. (1993). More progress toward a taxonomy of managerial performance requirements. Human Performance, 6, 1-21. 